\title{
EUROPEAN SYSTEMS OF JURY TRIAL
}

\section{Veljko Turanjanin*}

\begin{abstract}
Systems of jury trials exist around the world and represent a characteristic of, primarily, Anglo-Saxon legal system. On the first place, the author emphasizes that in the world there exists two basic forms of citizen participation in trial. Nowadays, we have a clear jury system, where citizens make a special trial chamber, which determines the facts and resolves all issues on trials, and on the basis of fact answer the question whether the defendant is guilty or not. On the other hand, there is a mixed jury system, where citizens and judges have a single trial chamber, and where they have equal rights in the fact-finding and in the imposition of criminal sanctions. In the UK and Commonwealth countries, this type of trial has a long history. Nevertheless, in recent years, it experienced a renaissance over the world and has been established in those countries that never had the jury system, or they had it in some stage of their development. In this paper, the author deals with jury trials in some European countries, especially in Spain and Russia, and explains their legal solutions, which strengthen the security of the citizens in the legal system and rule of the law.
\end{abstract}

INTRODUCTION

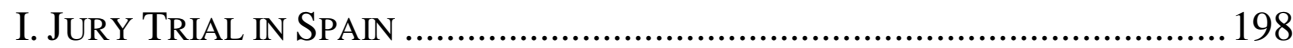

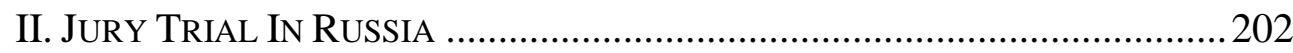

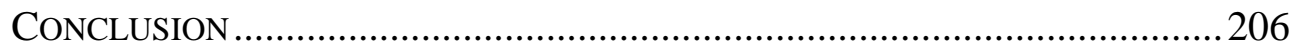

\section{INTRODUCTION}

The period of the major reform changes in the criminal procedure legislations across the European continent and the world, besides the other features, characterizes the different position of the defendant in the criminal procedure. Here, the author would not take into consideration defendant's rights and duties in the procedure, but the author will draw attention to the fact that it is not the same for the defendant whether, for the crime that he committed, the court is composed only by professional judges, or the court is composed by professional judges and lay persons (mixed court) or jury court composed only by citizens. This, in the nice way, illustrates the sentence that if the defendant is guilty for the crime, it is better for him to try before the Anglo-Saxon court, but if he is innocent, than a continental,

\footnotetext{
${ }^{*}$ Associate professor at the Faculty of Law, University of Kragujevac, Serbia; Secretary of Serbian Association of Criminal Law and Practice. Research fields: Criminal and Criminal Procedure Law. Acknowledgment: This work was supported by Faculty of Law, University of Kragujevac.
} 
European court, is better for him. ${ }^{1}$

Analyzing the judicial proceedings throughout the European continent, one can notice big differences in the systems of solving criminal cases, despite pronounced trends towards harmonization of legislations. For example, some countries base criminal procedure on the jurors (e.g. Spain, Russia), while others are not familiar with the lay participation (e.g. Bosnia and Herzegovina). Finally, some countries have both solutions, where citizens sit with professional judges and make a unique panel (e.g. France, Serbia). On the other hand, some legislators, because of fear of mistakes in the process, allow a wide range of reasons from which a prosecutor and defendant can attack verdict, while others strongly limit the same. In addition, some countries emphasize conducting the procedure by the court, while in the others, the court has a relatively passive role - in such countries activities, and thus a responsibility, which is left to the prosecutor and defense. $^{2}$

When the major reforms across the European continent have been occurring, structural and theoretical basis of the criminal proceedings is the matter of international interest. ${ }^{3}$ European legislators have begun to turn to countries in Anglo-Saxon legal tradition, which have come up the legal institutes that prove their effectiveness, thereby causing the deletion once tightly bounded boundaries that existed between the European and American legal system. ${ }^{4}$ In that way, they try to solve many issues, such as: whether the legal solutions provide efficiency in handling criminal matters, what the goals of the criminal proceedings are, what the social functions of trials are and whether it is possible to develop a normative theory of the trial, or indeed there is an optimal criminal procedure that combines principle of due process of finding efficient material truth. ${ }^{5}$ However, until they create a unique procedure, all countries in Europe create their own system of resolving criminal cases, and some of them in the legislation incorporated

\footnotetext{
${ }^{1}$ J. H. Merryman, R. Perez-Perdomo, The Civil Law Tradition: An Introduction to the Legal SySTEMS OF WeSTERn EUROPE AND LATIN AMERICA 127 (Stanford University Press 2007); M. Jimeno-Bulnes, American Criminal Procedure in a European Context, 21 CARdozo Journal OF INTERNATIONAL LAW \& COMPARATIVE LAW 409 (2013).

${ }^{2}$ W. Pizzi, Trials Without Truth: Why Our System of Criminal Trials Has Become an Expensive Failure and What We Need to Rebuild It? 115 (New York-London, New York Univesity Press 1999).

${ }^{3}$ S. Swoboda, A Normative Theory of Criminal Procedure, 18 CRIMINAL LAw ForUm 151 (2007).

${ }^{4}$ M. Damaska, The Fate of the Anglo-American Process Notion in Italy, 13(1) Croatian ANNUAL OF CRIMINAL LAW AND PRACTICE 3 (2006). Thus, the European legislation gradually incorporates instruments of disposition of criminal proceedings by parties in them. See also: M. Damaska, On Some Effects of the Party formed Preliminary Criminal Proceedeing, 14(1) Croatian ANnUAL of CRiminal LaW AND PRACTICE 3 (2007).

${ }^{5}$ S. Swoboda, A Normative Theory of Criminal Procedure 151.
} 
the system of real jury trial. Among the legal transplants that have found their place in the legislative solutions of continental European countries, by its features we can distinguish a jury.

Jury trials exist around the world, and represent a characteristic primarily of Anglo-Saxon legal system. Primarily, it should be noted that there are two basic forms of citizen's participation in trial. The first one is a real jury system, in which citizens themselves create special judicial panels, which determine the facts and resolve all issues of trial, and on these facts they determine whether defendant is guilty or not. The other one is a mixed jury system, as a form of trial where judges and jurors form a unique judge panel. ${ }^{6}$ England is as a cradle of jury system, which exports this own product to Australia, Canada, New Zealand, Republic of Ireland, Northern Ireland, Scotland, and United States, as well as to the other colonies in Africa and South America. ${ }^{7}$

Democratically oriented countries have recognized the importance of citizen's participation in trials for criminal matters, and in parallel with political and legal changes have begun to establish mechanisms of jury trial, while, on the other hand, it states that have established jury system continued maintenance of this tradition. ${ }^{8}$ Despite the fact that the percentage of criminal cases solved by jury in Anglo-Saxon countries has declined dramatically in the recent years, ${ }^{9}$ primarily due to alternative ways of solving them, a number of states that incorporated into their legal systems, some of the form of citizen participation in the trial, or at least, they debate about this issue, becomes striking. ${ }^{10}$ In this paper, the author deals with

\footnotetext{
${ }^{6}$ S. Bejatovic, Criminal Procedure Law 138-139 (Belgrade, Official Gazette 2014). As it is case with almost every major issues of criminal procedure, presence of citizens here has its supporters and opponents. See: V. Hans, Jury Systems around the World, CoRnell Law FACUlty PubliCATIONS 276 (2008). Jurors initially were not people who were in charge for hearing the evidence, but to present it, so they occupied the position of witness in the proceedings.

${ }^{7}$ N. Vidmar, Juries and Lay Assessors in the Commonwealth: A Contemporary Survey, 13 CRIMINAL LAW FORUM 385 (2002).

${ }^{8}$ N. Marder, An Introduction to Comparative Jury Systems, 86(2) ChiCAGo-Kent LAw Review 453 (2011).

${ }^{9}$ Trial by jury has represented the primary method of resolving of criminal cases in the AngloAmerican legal system for decades. However, in the recent years it has experienced a decrease, primarily due to the fact that more and more prosecutors take a major function of the judge in the proceedings. Additionaly, an important factor is the substantial increase of the costs of criminal proceedings, resulting in the seeking for the alternative means of dispute resolution, primarilly by plea agreements. Also, this legal system has major implications on the decrease of jury trials introduction of guidelines for punishment, which jury trials make a less attractive for the defendants. It consolidates the power of prosecutor to resolve a case through the plea negotiations. To ilustrate, the number of jury trials for the period from 1976 to 2002 decreased for $15 \%$. See more: V. Hans, The Twenty-First Century Jury: Worst of Times or Best of Times? 1 CRIMINAL LAW BRIEF 3 (2006).

${ }^{10}$ V. Hans, Jury Systems around the World 276.
} 
legislation of Spain and Russia, as countries with clear jury systems, but in some places will be mentioned solutions from other European systems that have mixed courts, such as France and Serbia.

\section{JURY TRIAL IN SPAIN}

The most direct impact of the philosophy of French revolution came to Spain through the works of Montesquieu and Rousseau, and through the capital work of Cesare Beccaria's On Crimes and Punishment. In order to achieve that the third branch of government, the judicial, be truly independent and invisible, Spanish legislator has provided legal instrument known as a jury, as a social instrument that belongs to the middle class and makes counterweight to the nobility. However, the jury trial in Spain is more similar to Anglo-Saxon model, unlike the French, which characterizes the participation of the professional judges and citizens together. ${ }^{11}$ The legislator has been introducing it in several attempts during nearly two centuries. Its traces are still visible in the Criminal Code of 1822, but we may consider that the most striking example of the jury is in the Press Law of 1820. Although its goal was not to regulate a jury, but for certain, crimes in this area a jury trial was provided. Legislator provided two types of jury, both for the crimes against the press (mostly due to violations of freedom of speech). One jury was composed by four citizens (Jurado de Acusación), and the other one by seven citizens (Jurado de Calificación). However, none of them functioned as expected, primarily due to the lack of independence from the executive branch, since the city council chose the jurors, where the power of different political groups was more than obvious. ${ }^{12}$

Jury trial, which we know today, is in the Spain legislation reintroduced by the Act of May 22, $1995^{13}$, after 60 years of its suspension under the Franco regime (Decree No. 138/1936 revoked jury trial). Reintegration of this legal transplant in the one European legislation raises the issue of whether the jury could be a catalyst in moving the legislation of this continent with a mixed criminal procedure system to adversarial, as it was during the French revolution. ${ }^{14}$

\footnotetext{
${ }^{11}$ M. Jimeno-Bulnes, Lay Participation in Spain: The Jury System, 14 InTERNATIONAL CRIMINAL JusTiCE REVIEW 166 (2004).

${ }^{12} \mathrm{Ibid}$, at 167.

${ }^{13}$ Ley Orgánica del Tribunal del Jurado, BolETín OfiCIAL DEL EsTADO, B.O.E. 122 (1995), with ammendments: Ley Orgánica no. 8/1995 of 16, November and Ley Orgánica no. 10/1995 of 23, November (further: Law of jury-LOJ).

${ }^{14}$ S. Thaman, Spain Returns to Trial by Jury, 21 HaSTINGS INTERNATIONAL AND COMPARATIVE LAw REVIEW 242 (1998).
} 
Nine citizens, chaired by professional judge, and two reserve jurors assemble jury court in Spain (Article 2. LOJ). Every person who wants to become a juror must meet some requirements. The first requirement is majority, which is repeatedly criticized many times. Therefore, there were proposals that this age limit should be increased to the 24 or 30 years. ${ }^{15}$ Then, a juror must be able to read and write, to be a resident in the province where the crime is committed, and that he does not have any physical, mental and sensory defect that prevents him from being a juror (Article 8 . LOJ).

A computer program selects jurors, and that program selects 36 potential jurors. In that way, it forms a proper list (Article 18 LOJ). After that, the court clerk sends them to complete a questionnaire (which includes all the necessary questions about the reasons of their potential inability of being jurors in particular case or general-Article 19 LOJ). Together with a questionnaire, a clerk sends a prospect to a jury, in order to ensure that jurors are fully informed about their role. The completed questionnaire should be returned to the court within five days of receipt. After completion of this part of procedure, there has to remain at least 20 potential jurors. At that point, the parties will select nine jurors, who take an oath (article 41 paragraph 1 LOJ). Jurors have an obligation to attend the trial for which they are elected. Hence, they have no right to refuse to be a juror. In the contrary, they could be subject of fines.

The defendant does not have a possibility of choice between a jury and the court made by professional judges. ${ }^{16}$ The legislator accurately determined which crimes are in competence of jury court. These are crimes against life, crimes committed by public officials, crimes against the

\footnotetext{
${ }^{15}$ M. Jimeno-Bulnes, Jury Selection and Jury Trial in Spain: Between Theory and Practice, 1(9) ONATI SOCIO-LEGAL SERIES 6 (2011).

${ }^{16}$ There are three ways for establishing jury trials, i.e. its binding for the certain fact. This can be the seriousness of the crime, which is reflected in the penalty that can be imposed, then, determining that the jury always tries in some instance, and the linkage of jury trial with the commision crimes that are taxative prescribed in the criminal codes. See: S. Thaman, Spain Returns to Trial by Jury 258-259. Spanish legislator, therefore, choose the third solution. For example, jury court in France is the court for the crimes that are punishable by imprisonment of at least ten years. The most common crimes on this court are murder, rape and robbery, while the less frequent are kidnapping, counterfeiting, terrorism (compare later with Russia) and crimes against humanity. See: R. Lettow Lerner, The Intersection of Two Systems: An American on Trial for an American Murder in French Cour D'Assises, UNIVERSITY OF ILLINOIS LAW REVIEW 804 (2001). Otherwise, it is not a permanent court. About it see: M. Bonnieu, The Presumption of Innocence and the Cour d'assises: Is France Ready for Adversarial Procedure? 72(1) REVUE InTERNATIONALE DE DROIT PÉNAL, 559 (2001). Serbian's mixed court has jurisdiction over the crimes that are punishable by imprisonment of at least eight years. See more: V. Turanjanin, Jury System in Serbia: One Step of Dissapperance, in CRIMINAL POLICY AS THE Instrument OF THE State's Politic ON THE CRime 395-412 (Banja Luka, Serbian Association for Criminal Law and Practice 2014).
} 
freedom and safety, and crime of causing a fire.

Since the principle of the material truth is one of the key principles in the American law, and in the laws of European countries, in the Spanish criminal procedure a judge leads a trial. He eliminates any discussion not related with the clarification of the truth, but at the same time, he does not deprive a necessary freedom of defense. ${ }^{17}$ With introduction of jury, legislator has deprived a judge of the absolute right to choose the questions that will be settled for witnesses, expert witnesses and accused. Jurors are authorized, in writing, to submit questions to the judge, who will, after the evaluation of its relevance, send them to the person who is questioned/examined (Article 46 paragraph 1 LOJ).

Prior to the closing words of the defendant, a professional judge prepares a list of questions for jurors (objecto del veredicto).$^{18}$ Some of the questions are in his favor, but some goes to his detriment. Questions are divided into two groups. The first group of questions are questions of proved or unproved act in the proceeding, and the second group are questions about guilt or innocence of the accused (Articles 59 and 60 LOJ). These are questions related to the fact that proves commission of the crime and the identity of the accused as the perpetrator; his claims facts that fully justify the commission of the crime, fact that shows the degree of participation of the defendant in the commission of the act, the aggravating and mitigating circumstances, and the defendant's plea-did he, or not, guilty for the crime. ${ }^{19}$ During the voting, existence of seven votes for the fact that is not in favor of accused is necessary, but for the facts in his favor, existence of five votes is sufficient (Article 59 paragraph 1 LOJ). After they finish voting about facts, the jury goes to the voting of defendant's guilt. For each part of the indictment, the jury vote separately, and seven votes for the fact that defendant is guilty is necessary, and five votes in order to consider that defendant is not guilty for specific charges (Article 60 paragraph 2 LOJ).

One of the major characteristics of Spanish jury system is legal condition that the jury verdict must be reasoned, which is not a feature of any other known model of jury trials. Classical Anglo-Saxon jury

\footnotetext{
${ }^{17}$ S. Thaman, Spain Returns to Trial by Jury 303-304.

${ }^{18}$ In particular cases, preparing the list may last few hours. See: S. Thaman, Spain Returns to Trial by Jury 352.

${ }^{19}$ S. Thaman, Should Criminal Juries Give Reasons for Their Verdicts?: The Spanish Experience and the Implications of the European Court of Human Rights Decision in Taxquet V. Belgium, 86 Chicago-Kent Law Review 628-629 (2011).
} 
characterizes provision that their verdict has to be "spontaneous", ${ }^{20}$ without any explanation. In this legislation, the law requires the jury to give reasons that justify the decision that certain facts are proved or not proved (Article 61 paragraph 1 LOJ). In order to avoid gaps in the verdict, the jury may request from the court secretary to assist in the preparation of its draft (Article 61 paragraph 2 LOJ). This was not a rarity, especially in the first jury trials in this country. ${ }^{21}$ After receiving a verdict, a judge has an obligation to review it, and, in a case that it has some flaws, requires from jurors to correct them (Article 63 LOJ). In fact, a judge will restore a verdict to the jury when it does not contain a decision in relation to the facts in that case, and about guilty for every person charged for the crime. In addition, a judge will restore a verdict in a case when there is lack of necessary majority in voting, or, if the decision about facts or about guilty is contradictory with proved facts, and if there is an error in the process of

\footnotetext{
${ }^{20}$ M. Jimeno-Bulnes, Lay Participation in Spain: The Jury System 179. However, due to the recent judgment of the European Court of Human Rights (Taxquet v Belgium, App. No. 926/05), in some jurisdictions, like France and Belgium, we have an attempts of reasoning of jury judgment. Due to this judgment, it is interesting to mention its impact on the national legislation of Belgium. In fact, the first judgment of the ECHR was against Belgium, because the court held that there was a violation of the article 6 of European Convention of Human Rights and Freedoms - a jury verdict has to contain a reasoning. Subsequently, the Belgian legislator has reacted and brought in the legislation a provision under which the jury is obliged to formulate the basic reasons for their decision. In addition, ECHR just initially held that the verdict has to contain reasons. In the final judgment in this criminal matter, the court has taken a completely opposite view. According to it, the Convention does not require from the jury to give reasons for its decision, which means that there is no violation of article 6 of Convention. Everything that is necessary is that the defendant and the public understand the judgement, which is an obstacle against arbitrariness. Anyway, the ECHR just upheld its decision from 1999, when it held that the court compensate the lack of reasoning with precisely certain issues and determining the direction to the jury how has to decide on these issues. In that way, the decision by jury without reasoning is not necesarily contrary to the Convention. J. Jackson, N. Kovalev, Lay Adjudication and Human Rights in Europe, 13 Columbia Journal of EuROPEAN LAW 116 (2006); judgment: Saric v. Denmark. http://hudoc.echr.coe.int/sites/fra/pages/search.aspx ?i=00121998\#\{\%22itemid\%22:[\%22001-21998\%22]\}, July 2014. However, warned with Belgian experience, the French courts have begun with endeavors in the making of reasoned judgments, through the large number of questions that the jury has to answer. On that basis, the court obtains an image on the reasons that have led the jury to the particular decision. See: V. Hans, C. Germain, The French Jury at a Crossroads, 86(2) CHICAGO-KENT LAW REVIEW 763 (2011). The practical question that arose is whether it is possible that the presiding judge develops in the difficult and complicate cases a detailed list of questions to get a proper reasoning. The answer is usually negative one. See: V. Hans, C. Germain, The French Jury at a Crossroads 763. See more: S. Thaman, Should Criminal Juries Give Reasons for Their Verdicts?: The Spanish Experience and the Implications of the European Court of Human Rights Decision in Taxquet v. Belgium 624; A. Doobay, The Right to a Fair Trial in the Light of the Recent ECtHR and CJEU Case-law, ERA FORUM (2013).

${ }^{21}$ S. Thaman, Europe's New Jury System: The Cases of Spain and Russia, 62(2) LAW AND CONTEMPORARY PROBLEMS 255 (1999).
} 
deliberation or voting (Article 63 paragraph 1 LOJ). ${ }^{22}$ However, if after the third returning of the judgment, the deficiencies are not corrected, or if the jury could not obtain necessary majority, a judge will dismiss the jury and maintain a new process with completely new jury. However, if a new jury faces with the same problem, a judge has an obligation to acquit a defendant. ${ }^{23}$ In any case, when the jury votes that defendant is not guilty for the crime, a judge is obliged to order his immediately release (Article 67 LOJ).

\section{JURY TRIAL IN RUSSIA}

Can such a delicate, complex and psychological case be submitted for decision to petty officials and even peasants? What can an official, still more a peasant, understand in such an affair? (F. M. Dostoevsky-The Brothers Karamazov)

Their faces all had a look of satisfaction at the prospect of fulfilling a public duty, although many of them had had to leave their businesses, and the most were complaining of it. (L. Tolstoy-Resurrection)

The legislator in Russia introduced a jury during the judiciary reform in the year of 1993. That was the year when a legislator brought a new Constitution of Russia Federation. ${ }^{24}$ That reform was a kind of revolution in Russian legislation, and it brought a plenty of innovations, which were regarded as a primary catalyst of democracy and humanization of the Soviet criminal justice system. ${ }^{25}$ Like many other countries, Russia faces escalation of crime. ${ }^{26}$ Therefore, Russia sought legislative changes, and among the largest, there was a shift from inquisitorial to adversarial procedure and return to jury system, while the main objective that should be reached was restoration of impaired confidence in the legal system of Russia. During the period of existence of Soviet Union, judiciary was the least respected legal profession in the country. ${ }^{27}$ Access to the court was difficult, and membership in the Communist Party was a requirement for obtaining the judge title. Accordingly, judges were extended arm of the Party and

\footnotetext{
${ }^{22}$ S. Thaman, Should Criminal Juries Give Reasons for Their Verdicts?: The Spanish Experience and the Implications of the European Court of Human Rights Decision in Taxquet V. Belgium 629.

${ }^{23}$ S. Thaman, Europe's New Jury System: the Cases of Spain and Russia 256.

${ }^{24}$ Конституция Российской Федерации, Российская газета on December 25, 1993.

${ }^{25} \mathrm{~S}$. Thaman, The Nullification of the Russian Jury: Lessons for Jury-Inspired Reform in Eurasia and Beyond, 40 CORNELl INTERNATIONAL LAW JouRnAl 359 (2007).

${ }^{26}$ K. Sweet, Russian Law Enforcement Under President Putin, Human Rights Review 20 (JulySeptember 2002).

${ }^{27}$ S. Boylan, The Status of Judicial Reform in Russia, 13 AMERICAN UNIVERSITY INTERNATIONAL LAw ReviEw 1327 (1998); K. Sweet, Russian Law Enforcement Under President Putin 29.
} 
followed the directives that are laid down in the higher hierarchical levels. $^{28}$

The legislator through the new Russian Criminal Procedure Code ${ }^{29}$, in which preparation American experts were involved, clearly promotes adversarial procedure and principle of equality, and prescribes that the functions of prosecution, defense and judiciary have to be separated. In addition, prosecutor and accused will be equal parties in the criminal proceedings (Article $15 \mathrm{CPC}$ and Article 123 of Russian Constitution). It also emphasizes the principle of material truth, right to privacy, right to human dignity, right to fair trial etc. ${ }^{30}$ Among the novelties contained in the $\mathrm{CPC}$ can be extracted the presumption of innocence, right to remain silence, defendant's right to be informed about his rights, adversarial process, possibility of the resolving a case in the early stage of proceeding, an investigation, ${ }^{31}$ a new way of trial organization, right to the lawyer, ${ }^{32}$ plea agreement, ${ }^{33}$ bail and etc. ${ }^{34}$ However, the reform in the Russian judiciary has been incomplete, primarily because of the fact that the reform was partial. It contributed to the improvement of the judiciary. Russian criminal proceeding in the Soviet Union and Russia for many years was based on the inquisitorial proceeding.

During 1993 and 1994, the foundations for revolutionary reform of the Russia's justice system were laid down. Reintegration of the jury and adoption of the Jury law have become a subject of the political struggle. In the last quarter of the 1992 were passed three drafts of the legal texts (the first was prepared in the late October, the second in the November, and the third at the end of the December of the same year). ${ }^{35}$ In this reform, the

\footnotetext{
${ }^{28}$ L. Aron, Russia Reinvents the Rule of Law, AMERICAN ENTERPRISE FOR PUblic POLICy RESEARCH 1 (2002).

${ }^{29}$ Уголовный Кодекс Российской Федерации оn Jun. 13, 1996. N 63-Ф3, Российская газета број 113 on Jun. 18, 1996, with later amendments in 1998, 1999, 2001, 2002, 2003, 2004, 2005, 2006, 2009 and 2011 (further: CPC).

${ }^{30} \mathrm{~S}$. Thaman, The Two Faces of Justice in the Post-Soviet Legal Sphere: Adversarial Procedure, Jury Trial, Plea Bargaining and the Inquisitorial Legacy, in CRIME, PROCEDURE AND EVIDENCE IN A

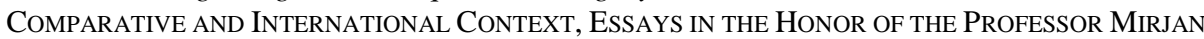
DAMASKA 102 (2008).

${ }^{31}$ About new solutions in the investigation, see K. Ershov, Russian Federation's Law No. 87-FZ: Political Machination or Procedural Reform, 1(7) PaCe International Law Review1-21 (2010).

${ }^{32}$ P. de Muniz, Judicial Reform in Russia: Russia Looks to the Past to create a New Adversarial System of Criminal Justice, Willamette Journal of InTERNATIONAL LaW \& DisPute Resolution 102-112 (2004).

${ }^{33}$ See V. Turanjanin, The Introduction of Adversarial System in Russia through the Review of the Two Major Institute-A Jury and Plea Bargaining, 2(3) HERALD OF LAW 65-81 (2011).

${ }^{34}$ L. Aron, Russia Reinvents the Rule of Law 12

${ }^{35} \mathrm{~S}$. Thaman, The Resurrection of Trial by Jury in Russia 79.
} 
jury ${ }^{36}$ becomes one of the main features of the adversarial system. Preliminary and experimental, the jury was introduced in nine states of Russian federation. Few years after that step, the legislator extended the jury system through the whole country, except Chechnya, where he established a jury in 2010. However, the introduction of jury has caused concern. Among the others, there is a fact that a jury released criminals who re-commit crimes after that. ${ }^{37}$ But, those are cases that occur in every criminal procedure system, not only in the jury system.

The jury is competent to judge only for serious crimes. It is possible to impose a term of imprisonment of ten years or longer for those crimes. ${ }^{38}$ However, the legislator decided that crimes of terrorism exclude from the jurisdiction of the jury, and, recently, constitutional court has confirmed this decision. ${ }^{39}$ During their jury duties, jurors are protected from attacks on their personality, both officers and citizens who want to disrupt their duties. In addition, law protects them from the political influence of the highranking officials, and anybody who wants to make the impact on jurors can be a subject of criminal proceeding. ${ }^{40}$

Potential jurors for each case are selected from the list of persons who have a right to vote (Article $325 \mathrm{CPC}$ ). They have to be citizens of Russia and have at least 25 years. Legislator does not require exact number of potential jurors, not the maximum number of jurors on the list. However, the list has to contain at least 20 names of citizens, chosen randomly, and the judge has a task to select jurors for particular trial (Article 325. paragraph 4

\footnotetext{
${ }^{36}$ In Russia existed jury system in period of year 1866-1917, when it was, together with advocacy, represented "beloved institution of the liberal party". See F. NetherCotT, RuSSIA Legal Culture Before and After Communism: Criminal Justice, Politics, and the Public Sphere 12 (London, Routledge 2007). About jury in that period see J. Diehm, The Introduction of Jury Trials and Adversarial Elements into the Former Soviet Union and Other Inquisitorial Countries, 11 JouRNAL of TRANSNATIONAL LAW \& POLICY 31 (2001). Although the jury trial raised some issues, primarily related to entrusting to the jury to solve serious cases, it did not last too long, since it terminated during the Bolshevik reign on 1917, by its Decree no. 1 on 17 December. See F. Davis, S. Tyulkina, Terrorism and Trial by Jury in Russia 5 (December 2013). Available at http://papers.ssrn.com/sol3/papers.cfm?abstract_id=2133235. Until that moment, the jury decided over 7.5 million cases. J. Coughenour, Reflections on Russia's Revival of Trial by Jury: History Demands That We Ask Difficult Questions Regarding Terror Trials, Procedures to Combat Terrorism, and Our Federal Sentencing Regime, 26 SeAttLe University Law ReVIEW 405 (2003).

${ }^{37}$ N. Kovalev, A. Smirnov, The Nature of the Russian Trial by Jury: "Jurata Patriae" or "Raison d'État”, 22 European Journal of Crime, Criminal LaW and Criminal Justice 116 (2014).

${ }^{38}$ J. Coughenour, Reflections on Russia's Revival of Trial by Jury: History Demands That We Ask Difficult Questions Regarding Terror Trials, Procedures to Combat Terrorism, and Our Federal Sentencing Regime 407.

${ }^{39}$ N. Kovalev, A. Smirnov, The Nature of the Russian Trial by Jury: "Jurata Patriae" or "Raison d'État" 120.

${ }^{40}$ S. Plotkin, The Jury Trial in Russia, 2 Tulane JOURnAl of InTERNATIONAL \& COMPARATIVE LAW 5-6 (1994).
} 
CPC). He will ask potential jurors about issues related to their years of life, abilities to speak and understand Russian language, mental disabilities that may affect their ability to serve as jurors, previous participation as juror during the same calendar year, and about their criminal record. The judge will ask other questions for which a citizen may refuse a jury duty. Although Russian legislator nowhere prescribes reasons for automatic disqualification of person who carries out certain function, it is considered that judges and prosecutors can be relieved from the jury duty if they call for that reason. ${ }^{41}$ Elimination method will select 14 jurors, whose names will be put in the box. From that box, a judge will bring out 12 names, while the other two potential jurors will serve as reserve jurors. On the trial, jurors will take place opposite to the defendant. ${ }^{42}$

Defendant has to invoke the jury if he wants such kind of trial. He has to know in the procedure that he has a choice - to be tried by a jury or a court composed by professional judge and two jurors, and the legal consequences for any of these options. Statistic shows that in the period 1994-2001 23\% of accused in the Russia exercise the right to the jury trial, while in the year of 2002 that percentage was $25 \% .{ }^{43}$ Otherwise, in this period on average, each year approximately 360 defendants required a jury trial, and the jury in the approximately $18 \%$ of the cases acquitted defendant. ${ }^{44}$ In this place, the author should mention the fact that, according to the research from the year of 2006, 31\% of respondents said that introduction of jury trial was a positive step in the Russian judiciary, and $44 \%$ would recommend a jury trial rather than trial with professional judge to his relatives, if necessary. However, $51 \%$ of respondents believe that it is difficult to be an impartial juror in this time, because the jurors are venal, while $43 \%$ of people would avoid this duty. ${ }^{45}$

After reading the indictment, defendant declares whether he understands the indictment and whether he considers himself guilty for a charged crime, followed by opening statements of the parties, in the first place by prosecutor, and then a defense. The prosecutor will present the evidences gathered about the defendant's guilt, whereupon defendant and his defense counsel have an opportunity to present their evidences (Article

\footnotetext{
${ }^{41}$ N. Kovalev, Jury Trials for Violent Hate Crimes in Russia: Is Russian Justice Only for Ethnic Russians? 86(2) CHICAGO-KeNT LAW REVIEW 692-693 (2011).

${ }^{42}$ S. Plotkin, The Jury Trial in Russia 10.

${ }^{43} \mathrm{~K}$. Sweet, Russian Law Enforcement under President Putin 30.

${ }^{44}$ K. Y. Ok, Study on Russian Jury System 11 (December 2013). Available at http://src-

h.slav.hokudai.ac.jp/.

${ }^{45} \mathrm{~S}$. Thaman, The Good, The Bad, or the Indifferent: 12 Angry Men in Russia, 82 CHICAGo-KenT LAW REVIEW 18 (2007).
} 
273-274 CPC). Closing arguments leads to the phase in which the court will briefly explain the criminal case in that proceeding, by summarizing undertaken evidentiary actions and attitudes of the parties, followed by formulation of the issues submitted to the jury, which will be related to the crime, identity of the defendant, his guilt, and aggravating and mitigating circumstances. The court emphasizes to the jury importance of presumption of innocence and the absence of the presumption of guilt in a case where accused defended himself by silence. ${ }^{46}$

The estimated period in which the jury should bring unanimous decision of the guilty of the accused is three hours from the beginning of the jury session, unless jury decides in shorter period of time that was anticipated. ${ }^{47}$ However, if after basic anticipated legal deadline for making a decision, the jury does not agree unanimous, then it goes to counting of votes and decides on basis of their majority. By adopting their decision, the court prepares a judgment that can be guilty or acquittal, depending on the decision made by a jury, which is binding for the court. The verdict can be subject of appeal to the Supreme Court for violation of the law, improper application of the criminal law, violations of the criminal proceeding or because the verdict was not fair (Article $379 \mathrm{CPC}$ ). When the judgment has acquired the status of finality, it may be disputed only in proceedings on extraordinary legal remedies: reviewing and repeating the process (Article 409 CPC).

\section{CONCLUSION}

The end of the 20th century and beginning of the 21 st century brought many changes in the modern criminal procedures codes around the world. Encountering the accumulation of the criminal cases in courts and inefficient criminal proceedings, the states, with great enthusiasm, started to search solutions in the comparative jurisdictions, adopting solutions that were previously incompatible with the continental laws. One of the solutions, compatible with the criminal process culture of concrete state, is legal institute known as a jury, which in its pure form came to the courts in the jurisdictions of Spain and Russia. Although there are two completely different legal systems, legislators in both of them have revived the jury system, which existed in the one period of their history in them. In addition,

\footnotetext{
${ }^{46} \mathrm{~S}$. Thaman, The Nullification of the Russian Jury: Lessons for Jury-Inspired Reform in Eurasia and Beyond 366 .

${ }^{47}$ The situation in the Russian jury system we can observe through the movie of Nikita Mihalkov " 12 ", which is a remake of the famous movie " 12 angry jurors", adapted to the Russian criminal procedure system.
} 
jury system in Russia is very similar to the American form of the citizen's participation in trial for crimes, while in the Spain exists sui generis solution that does not exist in any other country in the Europe. However, regardless to the differences in the implementation of jury trials, in both countries is the main consideration that jury is additionally secure element of democracy and protection of the defendant's rights in criminal procedure. 